\title{
Analysis of Cardiovascular Drugs Inventory Control Using ABC- EOQ-ROP-SS Method at Jakarta Islamic Hospital
} \author{
IN DEX I N G \\ Keywords: \\ Cardiovascular \\ Drugs; \\ Inventory Control; \\ $\mathrm{ABC}$ Investment; \\ Economic Order; \\ Reorder Point; \\ Safety Stock;
}

Nopiana $^{1}$, Atik Nurwahyuni ${ }^{2}$

${ }^{1}$ Correspondence Author: nopiana91@ui.ac.id

${ }^{1}$ Hospital Administration Studies, Faculty of Public Health University of Indonesia, West Java, Indonesia ${ }^{2}$ Health Policy and Administration Department, Faculty of Public Health University of Indonesia, West Java, Indonesia

Kata kunci:

Obat Kardiovaskular Pengendalian

Persediaan;

$\mathrm{ABC}$ investasi;

Pemesanan Ekonomis;

Titik Pemesanan Ulang;

Stok Pengaman; \begin{abstract}
A B S T R AC T
Cardiovascular disease was still a global threat and give a major role as the number one cause of death in the world. Patients with CVDs should take the medication regularly so that the availability of these drugs in health facilities must be maintained. And then, Cardiovascular drugs were the highest usage costs during 2019, which is around Rp. 6,924,415,718.20 (22.62\%) so that it requires special attention to control the inventory. The object of this research was to determine the implementation of cardiovascular drug inventory control using ABC-EOQ-ROP-SS method to minimize the stock inventory, while maintaining the service level. This research used a nonexperimental comparative method with retrospective cardiovascular drug data collection in 2019. Data obtained through the documentation of the Pharmacy Installation section and the logistics section. The data were analyzed to determine the cost efficiency of cardiovascular drugs using the ABC-EOQ-ROP-SS method compared to actual data for drug orders in January-December 2019 .The results of ABC-EOQROP-SS methods in controlling cardiovascular drugs can be implemented by the Jakarta Islamic Hospital to minimize stock inventory, while maintaining the service level and can increase the total cost efficiency up to $17,91 \%$ of the actual order .
\end{abstract}

Penyakit kardiovaskuler masih menjadi ancaman global dan berperan besar sebagai penyebab kematian nomor satu di dunia. Penderita CVD diharuskan untuk mengkonsumsi obat secara rutin sehingga ketersediaan obat tersebut di fasilitas kesehatan harus tetap terjaga. Kemudian, obat kardiovaskular merupakan obat dengan biaya pemakaian tertinggi selama tahun 2019, yaitu sekitar Rp. 6.924.415.718,20 $(22,62 \%)$ sehingga perlu perhatian khusus dalam pengendalian persediaannya. Tujuan penelitian ini adalah untuk mengetahui pelaksanaan pengendalian persediaan obat kardiovaskular dengan metode ABC-EOQ-ROP-SS untuk meminimalkan total biaya persediaan, dengan tetap memperthankan tingkat pelayanan. Penelitian ini menggunakan metode komparatif non eksperimental dengan pengumpulan data obat kardiovaskular secara retrospektif pada periode Januari - Desember tahun 2019. Data diperoleh melalui dokumentasi bagian Instalasi Farmasi dan bagian logistik. Analisis data dilakukan untuk mengetahui efisiensi biaya obat kardiovaskular dengan metode ABC-EOQ-ROP-SS dibandingkan dengan data aktual pesanan obat tahun 2019.Hasil penelitian menunjukkan bahwa pengendalian obat kardiovaskular dengan metode ABC-EOQ-ROP-SS diketahui dapat dilaksanakan di Rumah Sakit Islam Jakarta untuk meminimalkan stok persediaan, dengan tetap menjaga kinerja pelayanan dan meningkatkan efisiensi biaya sekitar 17,91\% dari biaya pemesanan aktual.

(C) 2020 JMMR. All rights reserved

Article history: Received 2020-11-24; Revised 2020-12-03; Accepted 2020-12-29

\section{INTRODUCTION}

Cardiovascular disease is still a global threat and give a major role as the number one cause of death. In 2015, data from WHO shows that 17.7 million from 39.5 million deaths by CVDs (WHO, 2017). In Indonesia, based on data from Basic Health Research in 2018, at least 15 out of 1000 people or about 2,784,064 individuals suffer from the disease (Riskesdas, 2018). Patients with CVDs should take the medication regularly. Patients with cardiovascular disease who withdraw from medication (aspirin) have an increased risk of 
cardiovascular events $>30 \%$ (Sundström et al., 2017). Similar to a previous study, patients post myocardial infarction who routinely consumption secondary prevention drugs had significantly better event-free survival, with a $27 \%$ reduction in risk of MACE (major adverse cardiovascular events) (Bansilal et al., 2016).

Cardiovascular drugs are vital and essential drugs that must be available in the hospital. The continuous availability of essential drugs within healthcare facilities plays an important role in promoting access and utilization of health services (Kuwawenaruwa, Wyss, Wiedenmayer, Metta, \& Tediosi, 2020). Drug availability positively affects patient trust in health care providers (Shan et al., 2016). Trust in health care providers is important; it shapes health service utilization patterns affect treatment compliance (Brennan et al., 2013) and encourages communication with service providers (Al-Mandhary, Al-Zakwani, \& Afifi, 2007).

However, hospitals cannot store a large amount of every drug because of limited budget. The hospital budget for drugs is the largest component of hospital expenditure. In many developing countries, the expenditure on hospital medicines can account for about 40 to $50 \%$ of total hospital cost (Kemenkes, 2016). With the limited budget, hospital has tomaintain the drug availability by enhancing inventory control management. Pharmacy logistic needs to monitor levels of inventory and determine what levels should be maintained, when stock should be replenished, and how large amount should be in order to keep inventory cost as minimum as possible while maintaining high customer service level (Jacobs, F. R., Chase, R. B., \& Aquilano, 2011).

From the research on inventory control at local hospitals in Bandung, it can be seen that the hospital has a potential savings of IDR $829,655,791(56.93 \%)$ of the overstock cost of the pharmaceutical unit (Hafnika, F., Farmaciawaty, DA., Adhiutama, A., \& Basri, 2016). Another study states the optimal inventory control can save up to $10 \%$ in the cost of administering drug supplies. The operational costs of managing drug supply chain at a hospital can reach $40 \%$ of the total operating costs, therefore it is very important for a hospital to improve its inventory control system (MWise, 2010).

Research on cytostatic drug inventory control at Moewardi Hospital, Surakarta, in 2012, controlling cytostatic drugs using the EOQ analysis method is known to increase cost efficiency up to Rp. $224,845,245$ or $73 \%$ of the total inventory cost of Rp. 306,956,410 (Widodo, 2012) . In the Jakarta Islamic Hospital, drug supply control uses the minimum maximum stock level method. Minimum stock for 7 days and maximum for 14 days. However, this minimum and maximum stock causes a lot of inventory in warehouses and pharmacies. The purpose of this research was to determine the implementation and efficiency of controlling cardiovascular drug using the ABC-EOQ-ROP-SS method.

\section{RESEARCH METHOD}

This research is a type of quantitative research using comparative non-experimental methods. This study used secondary data of 225 items of cardiovascular drugs during 2019 at the Jakarta Islamic Hospital. Data were analyzed to determine the cost efficiency of cardiovascular drugs using the ABC-EOQ-ROP-SS method. Result of this research was tested using the Paired-Sample $t$ test. This research was done in January - March 2020. At the beginning of the research, all cardiovascular drug items were classified according to the $A B C$ (Always, Better, Control) classification. The ABC classification use the Pareto Principle, which show that a small number of items account for a small rupiah volume and a large 
number of items account for a small rupiah volume (Hafnika, F., Farmaciawaty, DA., Adhiutama, A., \& Basri, 2016). ABC method classify inventory based on rupiah volume into three categories, which are high rupiah volume (A); moderate rupiah volume (B); low rupiah volume (C). For A items typically only $20 \%$ of the total items, but account for nearly $70 \%$ of the total usage. B items typically compose about $30 \%$ of the total items and about $20 \%$ of the total usage. $\mathrm{C}$ items account for the remaining $50 \%$ of the total items and the remaining $10 \%$ of the total costs. Therefore, A items should be inspected and reorder daily, or near daily (Seto, 2004).

Furthermore, the researcher calculated EOQ (Economic Order Quantity) value in category $\mathrm{A}$ on the $\mathrm{ABC}$ calcification results. $\mathrm{EOQ}$ is a formula to determine the number of quantity orders that minimizes ordering costs and carrying costs. EOQ (Economic Order Quantity) uses the assumption of constant demand, constant waiting time, and fixed order costs per order (Waters, 2003). The Economic Order Quantity was calculated using formula:

Whereas;

$$
E O Q=\sqrt{\frac{2 D O}{C}}
$$

$E O Q=$ Economic order quantity

$D=$ Annual demand

$\mathrm{O}=$ Ordering cost $(\mathrm{Rp} /$ order $)$

$\mathrm{C}=$ Carrying cost $(\mathrm{Rp} /$ unit-year $)$

After determining the EOQ, the next step is to determine when the purchasing need to reorder. Reorder points (ROP) is the limit of the amount of stock that is still there. What needs to be taken into account is the time it takes between an order to be placed and the goods are received. At that time interval, there must be a guarantee that supplies remain so that they do not interfere with service. ROP can calculate using a formula (Peterson \& Kelly, 2004):

$\mathrm{ROP}=(d x L)+S S$

Whereas:

$\mathrm{ROP}=$ Re-Order Point

$\mathrm{d}=$ Average demand per period

$\mathrm{L}=$ Lead time

SS $=$ Safety Stock

ROP also considers the importance of safety stock to anticipate uncertain demand / need. Safety stock is a buffer stock that is stored to accommodate an increase in demand or lead time that exceeds the estimated time. Safety stock can be calculated using statistical methods with formulas (Waters, 2003):

Whereas:

$$
\mathrm{SS}=Z x s d x \sqrt{L}
$$

SS = Safety Stock

$\mathrm{Z}=$ Service level constant

$\mathrm{Sd}=$ Standard deviation of demand

$\mathrm{L}=$ Lead time 
To determine the efficiency obtained from inventory control of cardiovascular drug, the researcher compared the total ordering cost and the total carrying between orders with the EOQ method and the actual orders. We can calculate the cost per unit by using formula: $\mathrm{TC}=$ total reorder costs + total carrying costs $=$

$$
=\mathrm{OD} / \mathrm{Q}+\mathrm{CQ} / 2
$$

Whereas:

$\mathrm{TC}=$ Total Cost

$\mathrm{O}=$ Ordering cost $(\mathrm{Rp} /$ order $)$

$\mathrm{D}=$ Annual Demand

$\mathrm{C}=$ Carrying Cost $(\mathrm{Rp} /$ unit-year $)$

$\mathrm{Q}=$ Quantity Order

\section{RESULT AND DISCUSSION}

\section{Analysis of $\mathrm{ABC}$ Investment}

The results of the $\mathrm{ABC}$ classification based on investment value of cardiovascular drugs are shown in the table I. It's shows that the results of ABC classification on 225 items of cardiovascular drugs obtained category A of 23 drug items (10.22\%) with an investment value of Rp. 4,839,738,131 (69.89\%), category B as many as 38 items of medicine (16.89\%) with an investment value of Rp. 1,426,359,595 (20.60\%), and category B as many as 164 items of medicine (72.89\%) with an investment value of Rp. 658,317 .992 (9,51\%).

Table 1. The results of $\mathrm{ABC}$ classification on cardiovascular drugs based on the investment value

\begin{tabular}{ccccc}
\hline Category & \multicolumn{2}{c}{ Item } & \multicolumn{2}{c}{ Cost } \\
& Amount & Percentage (\%) & Amount (IDR) & Percentage (\%) \\
\hline A & 23 & 10,22 & 4.839 .738 .131 & 69,89 \\
B & 38 & 16,89 & 1.426 .359 .595 & 20,60 \\
C & 164 & 72,89 & 658.317 .992 & 9,51 \\
& 225 & 100 & 6.924 .415 .718 & 100 \\
\hline
\end{tabular}

The results of categories $\mathrm{A}, \mathrm{B}$ and $\mathrm{C}$ are directly proportional to the amount of drug use by cardiovascular patients at the Jakarta Islamic Hospital. This shows that the drug inventory control is less effective and efficient because it is not suitable for drug inventory in general. Based on the inventory control delivered by Seto, that category A represents $20 \%$ of drugs in stock and $70 \%$ of total sales (Seto, 2004). Meanwhile, category A in the Jakarta Islamic Hospital was only $10.22 \%$. This means that there is an over stock of category A cardiovascular drug.

\section{Analysis of Economic Order Quantity (EOQ)}

EOQ calculation is only performed for category A cardiovascular drugs because it is assumed that demand for category A drugs is constant. In determining the optimum order quantity using the EOQ method, it is necessary to calculate the number of annual demands, ordering costs and carrying costs. The annual demand based on data consumption during 2019. Ordering cost include costs required to place an order, including telephone fees and stationary fees, and employee fee. The carrying cost in this research was calculated using the theoretical of Waters, which is $25 \%$ of the price unit item of drugs (Waters, 2003). 
Table.2 Stationary fess per order

\begin{tabular}{lcrr}
\hline \multicolumn{1}{c}{ Item } & Quantity & Price $(\mathrm{Rp})$ & \multicolumn{1}{c}{ Total $(\mathrm{Rp})$} \\
\hline Paper Cost & 13 & 434.500 & 5.648 .500 \\
Computer Tape Cost & 6 & 66.000 & 396.000 \\
Total Cost/Year & & & 6.044 .500 \\
Total Cost/Month & & & 503.708 \\
Cost per Order (1200 order) & & & 420 \\
\hline
\end{tabular}

Table.3 Employee Fees

\begin{tabular}{lr}
\hline \multicolumn{1}{c}{ Employee Fee } & Nominal (Rp) \\
\hline Employee Fee/Month & 6.200 .000 \\
Employee Fee Order/hour (150 hours/mounth) & 41.333 \\
Employee Fee per Order (10 minute/order) & 6.889 \\
\hline
\end{tabular}

Based on table.2 interviews, the average time needed to place an order is 6 minutes. Local call rates are IDR 300 per 3 minutes so the cost for 6 minutes of telephone calls is IDR 900. Details of stationary fees for each order can be seen in table 2. Based on the order data in 2019, the average order per month is 1200 order letters. Each order required duplicate paper and computer tape. It takes 1 person on duty to place an order and every month it takes 150 hours of work (6 hours of effective work multiplied by 25 days). It takes 10 minutes for each order to make so employee fee per order was IDR 6.889. Based on the table.3 details of the costs above, the order fee for each order is IDR 8,205.

After the ordering costs and carrying costs are known, the data is entered into the formula. For example, the EOQ calculation for Nitrokaf Retard 2.5 mg BPJS is as follows:

Annual Demand $=540,898$ capsules

Carrying Cost $=25 \% \times 1,560=\operatorname{IDR} 390,-$

Ordering Cost $=$ IDR 8,209

Then the Economic Order Quantity (EOQ) is:

$\mathrm{EOQ}=\sqrt{2 \mathrm{DO} / \mathrm{C}}$

$\mathrm{EOQ}=\sqrt{2} \times 540.898 \times 8.209 / 390$

$\mathrm{EOQ}=4,771$ capsules

Table.4 The value of EOQ (Economic Order Quantity) and the frequency of ordering each item of cardiovascular drugs category A, compared with the average number of orders and the average order frequency on actual data history

EOQ Order Frequency

\begin{tabular}{lcccccc}
\multicolumn{1}{c}{ Drug Name } & Price/Unit & $\begin{array}{c}\text { Annual } \\
\text { Demand }\end{array}$ & EOQ & $\begin{array}{c}\text { Actual } \\
\text { Average } \\
\text { Order }\end{array}$ & $\begin{array}{c}\text { By EOQ } \\
\text { formula }\end{array}$ & $\begin{array}{c}\text { By Actual } \\
\text { Average }\end{array}$ \\
\hline $\begin{array}{l}\text { Nitrokaf Retard } \\
\text { 2,5mg BPJS }\end{array}$ & $1.560,00$ & 540.898 & 4.771 & 9.200 & 113 & 60 \\
$\begin{array}{l}\text { Nitrokaf Retad } \\
\text { Forte 5mg BPJS }\end{array}$ & $2.401,99$ & 322.236 & 2.967 & 6.000 & 109 & 55 \\
\hline
\end{tabular}


Table.4 (continued) The value of EOQ (Economic Order Quantity) and the frequency of ordering each item of cardiovascular drugs category $\mathrm{A}$, compared with the average number of orders and the average order frequency on actual data history

\begin{tabular}{|c|c|c|c|c|c|c|}
\hline \multirow[b]{2}{*}{ Drug Name } & \multirow[b]{2}{*}{ Price/Unit } & \multirow[b]{2}{*}{$\begin{array}{l}\text { Annual } \\
\text { Demand }\end{array}$} & \multicolumn{2}{|c|}{ EOQ } & \multicolumn{2}{|c|}{ Order Frequency } \\
\hline & & & EOQ & $\begin{array}{r}\text { Actual } \\
\text { Average } \\
\text { Order }\end{array}$ & $\begin{array}{c}\text { By EOQ } \\
\text { formula }\end{array}$ & $\begin{array}{r}\text { By Actual } \\
\text { Average }\end{array}$ \\
\hline $\begin{array}{l}\text { Diviti PFS } \\
2.5 \mathrm{mg} / 0.5 \mathrm{ml} \mathrm{BPJS}\end{array}$ & $\begin{array}{r}237.177,0 \\
5\end{array}$ & 1.950 & 23 & 56 & 84 & 41 \\
\hline $\begin{array}{l}\text { Clopidogrel Tab } \\
75 \mathrm{mg} \text { BPJS }\end{array}$ & $1.403,82$ & 271.639 & 3.564 & 7.560 & 76 & 38 \\
\hline $\begin{array}{l}\text { Adalat Oros Tab } \\
30 \mathrm{mg} \text { BPJS }\end{array}$ & $3.948,00$ & 93.704 & 1.248 & 2.880 & 75 & 34 \\
\hline $\begin{array}{l}\text { Candesartan Tab } \\
\text { 16mg BPJS }\end{array}$ & 943,09 & 253.142 & 4.198 & 6.600 & 60 & 39 \\
\hline $\begin{array}{l}\text { Bisoprolol Tab 5mg } \\
\text { BPJS }\end{array}$ & 840,67 & 229.848 & 4.236 & 5.880 & 54 & 24 \\
\hline $\begin{array}{l}\text { V-Bloc Tab 6,25mg } \\
\text { BPJS }\end{array}$ & $1.500,00$ & 123.192 & 2.322 & 3.870 & 53 & 34 \\
\hline $\begin{array}{l}\text { Candesartan Tab 8mg } \\
\text { BPJS }\end{array}$ & 545,00 & 311.065 & 6.121 & 8.640 & 51 & 36 \\
\hline Miozidine Tab & $3.740,00$ & 36.874 & 804 & 1.020 & 46 & 37 \\
\hline $\begin{array}{l}\text { Candesartan Tab } \\
\text { 16mg }\end{array}$ & $7.150,00$ & 15.212 & 374 & 480 & 41 & 31 \\
\hline $\begin{array}{l}\text { Norephineprin Inj } \\
\text { BPJS }\end{array}$ & $25.839,00$ & 3.781 & 98 & 160 & 39 & 22 \\
\hline Vascon Inj & $\begin{array}{r}104.500,0 \\
0\end{array}$ & 883 & 24 & 40 & 37 & 16 \\
\hline Candesartan Tab 8mg & $4.500,00$ & 19.642 & 535 & 570 & 37 & 33 \\
\hline Canderin Tab 8mg & $7.700,00$ & 11.275 & 310 & 360 & 36 & 32 \\
\hline $\begin{array}{l}\text { Diviti PFS } \\
2.5 \mathrm{mg} / 0.5 \mathrm{ml}\end{array}$ & $\begin{array}{r}324.500,0 \\
0\end{array}$ & 266 & 7 & 14 & 36 & 18 \\
\hline Furosemid Inj & $3.410,00$ & 23.148 & 668 & 875 & 35 & 27 \\
\hline $\begin{array}{l}\text { Nitrokaf Retard } \\
2,5 \mathrm{mg}\end{array}$ & $2.706,00$ & 28.572 & 833 & 1.100 & 34 & 21 \\
\hline Micardis Tab 80mg & $24.534,19$ & 3.068 & 91 & 240 & 34 & 7 \\
\hline $\begin{array}{l}\text { Platogrix Tab 75mg } \\
\text { (AJI) }\end{array}$ & $4.400,00$ & 16.983 & 503 & 644 & 34 & 26 \\
\hline $\begin{array}{l}\text { Clopidogrel Tab } \\
75 \mathrm{mg}\end{array}$ & $5.536,67$ & 13.471 & 400 & 750 & 34 & 30 \\
\hline Canderin Tab 16mg & $9.900,00$ & 7.308 & 220 & 360 & 33 & 21 \\
\hline Atofar Tab 20mg & $12.100,00$ & 5.829 & 178 & 240 & 33 & 26 \\
\hline
\end{tabular}

In the table.4, this EOQ value was compared with the actual data on quantity drug orders for the period January to December 2019. For example, the number of economical orders for Nitrokaf Retard BPJS is 4,771 capsules with a frequency of 113 orders in a period of one year. This means that by ordering 4,771 capsules there is an optimal balance between ordering costs and carrying costs so that there is an efficiency between the investment value and the cost of drug supplies that must be 
incurred by the hospital. Using the same method, each drug can be determined the EOQ value and the frequency of ordering.

The frequency order of cardiovascular drugs is actually lower than the frequency of order of cardiovascular drugs based on the EOQ method. This can increase carrying costs even though ordering costs can decrease. The difference in the frequency of reality from EOQ shows inefficiency in ordering drug so that it will affect carrying costs. When the frequency order is increased, the cost emphasis occurs on carrying costs and reduces the risk of damage / expiration, even though the ordering costs increase, but there can be considerable cost efficiency (Widodo, 2012).

\section{Analysis of Re-Order Point (ROP) and Safety Stock (SS)}

Even though the number of orders is greater than the EOQ, there is still a possibility of a drug vacuum. This is due to the absence of determining the right time to order drugs. So that the EOQ value can be combined with the determination of the re-order point by considering safety stock. Safety stock is needed to prevent vacancies from occurring due to uncertainty in demand, delays in ordering, and delays in transportation when refilling (Heizer, 2015). The Safety Stock value and reorder point show in table 5.

Table 5. Economic Order Quantity (EOQ), Reorder Point (ROP), and Safety Stock (SS) calculation on category A cardiovascular drug

\begin{tabular}{lrrrr}
\hline \multicolumn{1}{c}{ Drug Name } & $\begin{array}{c}\text { Economic } \\
\text { Order } \\
\text { Quantity } \\
\text { (ROP) }\end{array}$ & $\begin{array}{c}\text { Order } \\
\text { Frequency/ } \\
\text { Year }\end{array}$ & $\begin{array}{c}\text { Safety } \\
\text { Stock (SS) }\end{array}$ & $\begin{array}{c}\text { Re-Order } \\
\text { Point } \\
\text { (ROP) }\end{array}$ \\
\hline Nitrokaf Retard 2,5mg BPJS & 4.771 & 113 & 255 & 4.822 \\
Nitrokaf Retad Forte 5mg BPJS & 2.967 & 109 & 193 & 2.660 \\
Diviti PFS 2.5mg/0.5ml BPJS & 23 & 84 & 2 & 16 \\
Clopidogrel Tab 75mg BPJS & 3.564 & 76 & 200 & 2.981 \\
Adalat Oros Tab 30mg BPJS & 1.248 & 75 & 46 & 759 \\
Candesartan Tab 16mg BPJS & 4.198 & 60 & 99 & 2.066 \\
Bisoprolol Tab 5mg BPJS & 4.236 & 54 & 96 & 1.779 \\
V-Bloc Tab 6,25mg BPJS & 2.322 & 53 & 99 & 967 \\
Candesartan Tab 8mg BPJS & 6.121 & 51 & 155 & 2.663 \\
Miozidine Tab & 804 & 46 & 38 & 352 \\
Candesartan Tab 16mg & 374 & 41 & 20 & 131 \\
Norephineprin Inj BPJS & 98 & 39 & 5 & 36 \\
Vascon Inj & 24 & 37 & 5 & 14 \\
Candesartan Tab 8mg & 535 & 37 & 26 & 192 \\
Canderin Tab 8mg & 310 & 36 & 10 & 96 \\
Diviti PFS 2.5mg/0.5ml & 7 & 36 & 1 & 3 \\
Furosemid Inj & 668 & 35 & 26 & 206 \\
Nitrokaf Retard 2,5mg & 833 & 34 & 42 & 290 \\
\hline
\end{tabular}


Table.5 (Continued) Economic Order Quantity (EOQ), Reorder Point (ROP), and Safety Stock (SS) calculation on category A cardiovascular drug

\begin{tabular}{lrrrr}
\multicolumn{1}{c}{ Drug Name } & $\begin{array}{c}\text { Economic } \\
\text { Order Quantity } \\
\text { (ROP) }\end{array}$ & $\begin{array}{c}\text { Order } \\
\text { Frequency/ } \\
\text { Year }\end{array}$ & $\begin{array}{c}\text { Safety } \\
\text { Stock (SS) }\end{array}$ & $\begin{array}{c}\text { Re-Order } \\
\text { Point } \\
\text { (ROP) }\end{array}$ \\
\hline Micardis Tab 80mg & 91 & 34 & 7 & 31 \\
Platogrix Tab 75mg (AJI) & 503 & 34 & 13 & 150 \\
Clopidogrel Tab 75mg & 400 & 34 & 71 & 209 \\
Canderin Tab 16mg & 220 & 33 & 11 & 66 \\
Atofar Tab 20mg & 178 & 33 & 22 & 67 \\
\hline
\end{tabular}

To calculate safety stock researchers used statistical methods. In calculating the safety stock, the service level that the management wants to achieve must be determined. According to Waters, the service level used is usually $95 \%$, resulting in a $\mathrm{Z}$ value $=1.64$. From the interviews with the informants, it was found that the lead time of the drugs averaged is 3 days. Based on table 5, each cardiovascular drug item has a varying ROP. Cardiovascular drug orders will only be carried out when stocks reach the ROP point. ROP is a way of procuring drugs by considering lead time, safety stock, and the number of needs. Leadtime is used to estimate an inventory arrives before the inventory runs out, while safety stock is a safety stock to avoid fluctuating demand (Waters, 2003).

This is an example of calculating the Safety Stock of Nitrokaf Retard $2.5 \mathrm{mg}$ BPJS:

Annual Demand $=45,671$ capsules

Lead time $(1)=3$ days

Service level $=95 \%$

Demand per day $=45,671 / 30$ days $=1,522$ capsules

Standard deviation of demand per day $=90$ capsules

$Z(95 \%)=1.65$

Safety Stock $=Z \times$ standard deviation of lead-time demand

$=\mathrm{Z} \sigma \sqrt{\mathrm{L}}$

$=1.65 \times 90 \times \sqrt{3}$

$=255$ capsules

So, safety stocks for Nitrokaf Retard 2,5 mg BPJS are 255 capsules.

ROP analysis

Known:

Demand per day $=1,522$ capsules

$\mathrm{L}=3$ days

$\mathrm{SS}=255$ capsules

So, the calculation is:

$\mathrm{ROP}=(\mathrm{d} \times \mathrm{L})+\mathrm{SS}$

$=(1,522 \times 3)+255=4,822$ capsules

So, the Reorder Point (ROP) for Nitrokaf Retard $2.5 \mathrm{mg}$ BPJS is 4,822 capsules

By using the ABC-EOQ-ROP-SS methods is expected to reduce the incidence of cardiovascular drug vacancies. The research that conducted by M. Burhan shows a significant influence the EOQ 
and ROP Methods to reduce frequency of drugs vacancy. He compared the number of drug vacancies before and after using the EOQ and ROP methods in drug inventory control, the effects were analyzed using the t-test (Burhan, M. Winarsih, Sri Harijanto, 2019).

\section{Analysis of Total Cost Between EOQ and Actual Order}

Table 6. The Result of Total Cost Between EOQ and Actual Order

\begin{tabular}{|c|c|c|c|c|c|c|}
\hline \multirow[b]{2}{*}{ Drug Name } & \multicolumn{3}{|c|}{ By EOQ } & \multicolumn{3}{|c|}{ By Actual Order } \\
\hline & $\begin{array}{l}\text { Orderring } \\
\text { Cost }\end{array}$ & $\begin{array}{l}\text { Carrying } \\
\text { Cost }\end{array}$ & Total Cost & $\begin{array}{l}\text { Orderring } \\
\text { Cost }\end{array}$ & $\begin{array}{l}\text { Carrying } \\
\text { Cost }\end{array}$ & Total Cost \\
\hline $\begin{array}{l}\text { Nitrokaf Retard } \\
\text { 2,5mg BPJS } \\
\text { Nitrokaf Retad }\end{array}$ & 930.671 & 930.344 & 1.861 .015 & 482.634 & 1.793 .998 & 2.276 .632 \\
\hline $\begin{array}{l}\text { Forte 5mg BPJS } \\
\text { Diviti PFS }\end{array}$ & 891.552 & 890.839 & 1.782 .391 & 440.873 & 1.801 .495 & 2.242 .367 \\
\hline $\begin{array}{l}2.5 \mathrm{mg} / 0.5 \mathrm{ml} \mathrm{BPJS} \\
\text { Clopidogrel Tab }\end{array}$ & 695.980 & 681.884 & 1.377 .864 & 285.849 & 1.660 .239 & 1.946 .088 \\
\hline $\begin{array}{l}75 \mathrm{mg} \text { BPJS } \\
\text { Adalat Oros Tab }\end{array}$ & 625.669 & 625.402 & 1.251 .071 & 294.958 & 1.326 .610 & 1.621 .568 \\
\hline $\begin{array}{l}\text { 30mg BPJS } \\
\text { Candesartan Tab }\end{array}$ & 616.359 & 615.888 & 1.232 .247 & 267.089 & 1.421 .280 & 1.688 .369 \\
\hline $\begin{array}{l}\text { 16mg BPJS } \\
\text { Bisoprolol Tab 5mg }\end{array}$ & 495.008 & 494.884 & 989.892 & 314.855 & 778.045 & 1.092 .900 \\
\hline $\begin{array}{l}\text { BPJS } \\
\text { V-Bloc Tab 6,25mg }\end{array}$ & 445.425 & 445.136 & 890.562 & 320.888 & 617.895 & 938.783 \\
\hline $\begin{array}{l}\text { BPJS } \\
\text { Candesartan Tab }\end{array}$ & 435.522 & 435.376 & 870.899 & 261.313 & 725.627 & 986.940 \\
\hline 8mg BPJS & 417.176 & 416.989 & 834.165 & 295.548 & 588.595 & 884.142 \\
\hline Miozidine Tab & 376.491 & 375.870 & 752.361 & 296.763 & 476.850 & 773.613 \\
\hline $\begin{array}{l}\text { Candesartan Tab } \\
\text { 16mg } \\
\text { Norephineprin Inj }\end{array}$ & 333.891 & 334.263 & 668.154 & 260.157 & 429.000 & 689.157 \\
\hline BPJS & 316.717 & 316.528 & 633.244 & 193.989 & 516.780 & 710.769 \\
\hline Vascon Inj & 302.023 & 313.500 & 615.523 & 181.214 & 522.500 & 703.714 \\
\hline $\begin{array}{l}\text { Candesartan Tab } \\
8 \mathrm{mg}\end{array}$ & 301.385 & 300.938 & 602.323 & 282.879 & 320.625 & 603.504 \\
\hline Canderin Tab 8mg & 298.569 & 298.375 & 596.944 & 257.101 & 346.500 & 603.601 \\
\hline $\begin{array}{l}\text { Diviti PFS } \\
2.5 \mathrm{mg} / 0.5 \mathrm{ml}\end{array}$ & 311.942 & 283.938 & 595.880 & 155.971 & 567.875 & 723.846 \\
\hline Furosemid Inj & 284.464 & 284.735 & 569.199 & 217.168 & 372.969 & 590.137 \\
\hline $\begin{array}{l}\text { Nitrokaf Retard } \\
2,5 \mathrm{mg}\end{array}$ & 281.570 & 281.762 & 563.332 & 213.225 & 372.075 & 585.300 \\
\hline Micardis Tab 80mg & 276.761 & 279.076 & 555.837 & 104.938 & 736.026 & 840.964 \\
\hline
\end{tabular}


Table 7. (continued) The Result of Total Cost Between EOQ and Actual Order

\begin{tabular}{lrrrrrr}
\hline \multicolumn{1}{c}{ Drug Name } & $\begin{array}{r}\text { Orderring } \\
\text { Cost }\end{array}$ & $\begin{array}{r}\text { Carrying } \\
\text { Cost }\end{array}$ & Total Cost & $\begin{array}{c}\text { Orderring } \\
\text { Cost }\end{array}$ & $\begin{array}{c}\text { Carrying } \\
\text { Cost }\end{array}$ & Total Cost \\
\hline $\begin{array}{l}\text { Platogrix Tab 75mg } \\
\text { (AJI) }\end{array}$ & 277.164 & 276.650 & 553.814 & 216.481 & 354.200 & 570.681 \\
$\begin{array}{l}\text { Clopidogrel Tab } \\
75 \mathrm{mg}\end{array}$ & 276.459 & 276.834 & 553.292 & 147.445 & 519.063 & 666.508 \\
Canderin Tab 16mg & 272.688 & 272.250 & 544.938 & 166.643 & 445.500 & 612.143 \\
Atofar Tab 20mg & 268.822 & 269.225 & 538.047 & 199.376 & 363.000 & 562.376 \\
Total Cost & 9.732 .308 & 9.700 .685 & 19.432 .993 & 5.857 .357 & 17.056 .745 & 22.914 .102 \\
\hline
\end{tabular}

Table 8 . The difference in total cost between an order by economic order and by actual order.

\begin{tabular}{ccccc}
\hline & By EOQ & $\begin{array}{c}\text { By Actual } \\
\text { Order }\end{array}$ & Difference & $\begin{array}{c}\text { Percentage } \\
(\%)\end{array}$ \\
\hline Order Cost & 9.732 .308 & 5.857 .357 & 3.874 .951 & 39,82 \\
Carrying Cost & 9.700 .685 & 17.056 .745 & -7.356 .060 & $-75,83$ \\
Total Cost & 19.432 .993 & 22.914 .102 & -3.481 .109 & $-17,91$ \\
\hline
\end{tabular}

In the table.7, We can see that the total reorder costs equal the total carrying costs in. This is always true if we use the economic order quantity. From table 7 it can be seen that ordering using the economic order quantity can save costs around $17.91 \%$ of the actual order. The results obtained differ greatly from the efficiency values obtained from Widodo's research which states that using the EOQ analysis method is known to increase the cost efficiency of cytostatic drugs by $73 \%$ of the total inventory cost. This is because the price per item of cardiovascular drug is cheaper than the price per item of cytotoxic drug so that the difference in the carrying cost is not too different (Widodo, 2012).

\section{CONCLUSION}

The results of ABC-EOQ-ROP-SS methods in controlling cardiovascular drugs can be implemented by the Jakarta Islamic Hospital to minimize stock inventory, while maintaining the service level and can increase the total cost efficiency up to $17,91 \%$ of the actual order. The hospital information system can support in fulfilling the data needed in the calculation of the ABC-EOQ-ROP-SS methods. The formula that has been determined must be able to be entered into the hospital information system so that stock travel can be evaluated quickly. Further research is needed for applicating this method for all of drugs item in Jakarta Islamic Hospital. In addition, the carrying costs can be more detailed than this research by calculate the electricity costs, storage facility costs, damaged and expired drugs costs, and personnel costs, compared to the total inventory in the end of the year. 


\section{ACKNOWLEDGEMENT}

I am grateful to the Director of the Jakarta Islamic Hospital for allowing me to conduct research in the hospital pharmacy.

\section{REFERENCES}

Al-Mandhary, A., Al-Zakwani, I., \& Afifi, M. (2007). Primary health care consumers' acceptance, trust and gender preferences towards omani doctors. Oman Medical Journal, 22(3), 51-56.

Bansilal, S., Castellano, J. M., Garrido, E., Wei, H. G., Freeman, A., Spettell, C., ... Fuster, V. (2016). Assessing the Impact of Medication Adherence on Long-Term Cardiovascular Outcomes. Journal of the American College of Cardiology, 68(8), 789-801. https://doi.org/10.1016/j.jacc.2016.06.005

Brennan, N., Barnes, R., Calnan, M., Corrigan, O., Dieppe, P., \& Entwistle, V. (2013). Trust in the health-care provider-patient relationship: A systematic mapping review of the evidence base. International Journal for Quality in Health Care, 25(6), 682-688. https://doi.org/10.1093/intqhc/mzt063

Burhan, M. Winarsih, Sri Harijanto, T. (2019). the Effect of Using the Abc-Eoq-Rop Method on the Frequency of Drug Emptiness in the Hospital. Jurnal Aplikasi Manajemen, 17(3), 451-463. https://doi.org/10.21776/ub.jam.2019.017.03.09

Hafnika, F., Farmaciawaty, DA., Adhiutama, A., \& Basri, M. (2016). Improvement of Inventory Control Using Continuous Review Policy in A Local Hospital at Bandung City, Indonesia. The Asian Journal of Technology Management (AJTM), 9(2), 109-119. https://doi.org/10.12695/ajtm.2016.9.2.5

Heizer, J. a. R. (2015). Operations Management: Sustainability and Supply Chain Management, [Manajemen Operasi: Manajemen Keberlangsungan dan Rantai Pasokan]. Jakarta: Salemba Empat.

Jacobs, F. R., Chase, R. B., \& Aquilano, N. (2011). Operations and supply chain management (Global ed). New York: Mc Graw Hill.

Kemenkes. (2016). Panduan Penggunaan Sistem Informasi Manajemen Logistik Di Instalasi Farmasi Pemerintah.

Kuwawenaruwa, A., Wyss, K., Wiedenmayer, K., Metta, E., \& Tediosi, F. (2020). The effects of medicines availability and stock-outs on household's utilization of healthcare services in Dodoma region, Tanzania. Health Policy and Planning, 35(3), 323-333. https://doi.org/10.1093/heapol/czz173

MWise, D. (2010). Not Your Father's Supply Chain. Materials Management in Health Care, 19(4), 30.

Peterson, A. M., \& Kelly, W. N. (2004). Managing Pharmacy Practice: Principles, Strategies, and Systems - CRC Press Book. In CRC Press. Retrieved from https://www.crcpress.com/Managing-Pharmacy-PracticePrinciples-Strategies-and-Systems/Peterson-Kelly/9780849314469

Riskesdas, K. (2018). Hasil Utama Riset Kesehata Dasar (RISKESDAS) (Vol. 44). https://doi.org/10.1088/1751$8113 / 44 / 8 / 085201$

Seto, S. (2004). Manajamen Farmasi. Surabaya: Airlangga University Press.

Shan, L., Li, Y., Ding, D., Wu, Q., Liu, C., Jiao, M., ... Ren, J. (2016). Patient satisfaction with hospital inpatient care: Effects of trust, medical insurance and perceived quality of care. PLoS ONE, 11(10), 1-18. https://doi.org/10.1371/journal.pone.0164366

Sundström, J., Hedberg, J., Thuresson, M., Aarskog, P., Johannesen, K. M., \& Oldgren, J. (2017). Low-dose aspirin discontinuation and risk of cardiovascular events: A swedish nationwide, population-based cohort study. Circulation, 136(13), 1183-1192. https://doi.org/10.1161/CIRCULATIONAHA.117.028321

Waters, D. (2003). Logistics: An Introduction to Supply Chain Management. In BMC Public Health. Great Britain: PALGRAVE MACMILLAN.

WHO. (2017). Cardiovascular diseases (CVDs). Retrieved from https://www.who.int/news-room/factsheets/detail/cardiovascular-diseases-(cvds)

Widodo, E. S. (2012). Analisis pengendalian obat sitostatika dengan metode eoq dan rop. 2012(April), $203-210$. 